Бауер В. В. Сношения Оосии с герианскими императорами в конше CXLVIII. C. 55-93.

Доронин А. В. Падение Константинополя в 1453 году и туреџкая угроза в ренессансной публиџистике // Новая и Новейшая история. 2015. № 3. С. 3-25.

Казакова Н. А. «Европейской страны короли» // Труды Ленинградского отделения Института истории СССР. М.; Л., 1964. Вып. 7. С. 418-426.

Казакова Н. А. Западная Европа в русской письменности XV-XVI веков. Из истории литературных связей России. Л., 1980.

Кудрявцев О. ФD. «Kayser vnnd Herscher aller Rewssen»: обрашение к русскому государю как к императору в габсбургских документах первой трети XVI в. // Древняя Русь. Вопросы медиевистики. 2016. № 1 (63). C. $41-55$.

Лобин A. Н. Планы военного сотрудничества Тевтонского ордена и России в 1517-1522 гг. // Studia Slavica et Balcanica Petropolitana. 2014. № 1 (15). C. 11-26.

Поляков И. А. Культурные аспекты обучения князя С.В. Ромодановского (1661-1680) // Мавродинские чтения 2018: Материалы Всероссийской науч. конф., посвяџенной 110-летию со дня рождения и профессора Владимира Васильевича Мавродина. СПб., 2018. С. 142-144.

Соболевский А. И. Переводная литература Московской Руси XIV-XVII вв.: Библиографические материалы. СПб., 1903.

Meurer P. Europa Regina. 16th century maps of Europe in the form of a queen // Belgeo. 2012. № 3-4. Р. 355-370 [Электронный ресурс]. URL: http://journals.openedition.org/belgeo/7711 (дата обрашения: 05.11.2018).

Stepan M. Shamin

The Institute of Russian History of the Russian Academy of Sciences, Moscow, Russia

\title{
“EUROPA REGINA” AND “THE EUROPEAN COUNTRY KINGS”: A MAP OF THE TIMES OF EMPEROR MAXIMILIAN I \\ IN THE MOSCOW STATE AT THE TURN OF THE $15^{\text {th }}$ AND $16^{\text {th }}$ CENTURIES
}

The study is dedicated to a short text "The European Country Kings" which is well-known in the Russian manuscripts since the beginning of the $16^{\text {th }}$ century. The author compares the essay with the inscriptions on the anthropomorphic maps "Europa Regina" ("Queen Europe"), published in 1537 and 1587. A comparison of Russian text with European maps shows that the "Europa Regina" edition issued in 1537 was not the first. It was preceded by a map created at the turn of the $15^{\text {th }}-16^{\text {th }}$ centuries during the reign of Emperor Maximilian I.

Keywords: "The European Country Kings", mas "Europa Regina”, Holy Roman Emperor Maximilian I

\section{УДК 94 (47) ББК 63.3(0)4 DOI 10.25986/IRI.2019.75.1.0037 \\ М. К. Юрасов \\ ИРИ РАН, Москва, Россия. mihail_yurasov@mail.ru \\ СРЕДНЕВЕКОВЫЕ ВЕНГЕРСКИЕ ХРОНИСТЫ $\mathrm{O}$ «УССКОЙ ПОЛИТИКЕ» СВОИХ КОРОЛЕЙ}

\begin{abstract}
Авторы средневековых исторических сочинений королевства Венгрии не одобряли политику своих королей по отношению к Руси, считая экспансию на восток бесперспективной. Формы такого неодобрения были различными: «урок королю», принижение успехов венгерского войска на русском направлении, но самым распространенным являлось игнорирование сведений о походах королевской армии на русские земли, как это показывает полное умолчание о попытках венгров закрепиться в юго-западной Руси в 1188-1190 и 1205-1234 г.

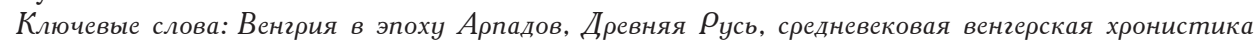

В средневековом королевстве Венгрии не сложилась развитая традиџия составления исторических сочинений. Погодные записи здесь представлены лишь предельно краткими Пожоньскими анналами (Annales Posonienses), а в хрониках периоды умолчания между подробными рассказами об отдельных событиях порой достигают одного-двух десятилетий даже при описании истории XII в. В связи с этим возникает вопрос о причинах такого умолчания, поскольку иностранные источники свидетельствуют об активной внешней политике Арпадов на всех направлениях. Учитывая то, что офиџиальные «Деяния венгров» («Gesta Hungarorum») регулярно дописывались и редактировались, можно предположить, что хронисты неслучайно оставляли без внимания многочисленные факты из жизни и деятельности своих королей и их приближенных, некоторые войны и вмешательство во внутренние дела других государств, видимо, осуждая действия Арпадов и их окружения. Весьма ярко это демонстрирует скупая информаџия венгерских хроник, касаюшаяся русско-венгерских отношений XI-XIII в.

Объектом моего исследования в данном случае является самое пространное произведение средневековой венгерской исторической мысли, которое принято называть Композиџией венгерских хроник XIV в. (Chronici Hungarici compositio saeculi XIV), известное в десятке списков, условно разделяемых на два «семейства» - 1) Будской; 2) Венской, или Иллюстрированной, хроник. Дошедшие до нас списки первой группы более краткие и, несмотря на свое более позднее происхождение, признаются содержашими более ранние тексты, чем рукописи второго «семейства». С точки зрения темы настояшей работы имеют научную џенность лишь списки второго «семейства». 
Хотя авторство различных эпизодов, описанных в Композиџии, принадлежит разным хронистам (некоторые из них гипотетически установлены венгерскими исследователями), в ракурсе настояџей работы это не имеет важного значения, поскольку оџенка политики Арпадов «на русском направлении» средневековыми книжниками была однозначной в различные эпохи. Считается, что первое офиџиальное историческое сочинение королевства Венгрии из тех, что вошли в Композиџию, было написано в последние годы правления Эндре (Андраша) I (1046-1060) или около 1066-1067 г., когда венгерский трон занимал его сын Шаламон (1063-1074) [Magyarország történeti kronológiája, 88-89. l.]. Доведена Композиџия венгерских хроник до 1342 г.

Если не считать полулегендарных сведений о взятии венграми Киева во время поисков новой родины в конџе IX в., то первый рассказ Композиџии, касаюшийся русско-венгерских отношений, связан с пребыванием герџогов Эндре (Андраша) и Левенте на Руси, где они скрывались от гнева своего двоюродного дяди - основателя Венгерского королевства Иштвана I Святого (1000/1001-1038), а после его смерти дожидались изменения политической ситуаџии в Венгрии в свою пользу. Уже в этом повествовании видно, что русское направление внешней политики Арпадов мало интересовало средневековых венгерских хронистов. Композиџия сообџает о перемешении герџогов, сначала вместе с братом Белой в Чехию и Польшу (гл. 78-79), а затем уже без Белы - на русское порубежье (гл. 80), где «правитель Лодомерии» (Владимира-Волынского) не позволил Эндре и Левенте перейти русскую граниџу, и лишь спустя какое-то время, когда им угрожала опасность быть убитыми печенегами, герџоги получили убежише на Руси $^{1}$. Никаких сведений о пребывании сыновей Вазула при дворе Ярослава Мудрого венгерские хронисты не сообшают. Об этом можно догадаться из известия гл. 81 о направлении венгерской знатью, недовольной правлением короля Петера Орсеоло (1038-1041, 1044-1046), послов на Русь с приглашением Эндре (Андрашу) занять престол ${ }^{2}$ В гл. 87 Композиџии кратко сообшается о том, что жена ставшего в 1046 г. королем Эндре (Андраша) I происходила из Руси ${ }^{3}$ Из всего этого и рассказа о захвате Эндре власти в Венгрии можно догадаться о том, что войско ему, скорее всего, дал его тесть Ярослав Мудрый.

Следуюшее известие Композиџии венгерских хроник, касающееся русско-венгерских отношений, содержится в гл. 111 и датируется исследователями около 1073 г. (в источнике дата отсутствует). Оно сообшает о том, что герџог Ласло, двоюродный брат короля Шаламона, приходившегося внуком Ярославу Мудрому, отправился на Русь искать помоџи своих друзей («auxilium amicorum suorum») против короля. Хронисты умалчивают о результатах этой поездки, но, судя по всему, помоши Ласло не нашел ${ }^{4}$. Тот же Ласло, но уже во время своего правления (Ласло I Святой, 1077-1095), появляется в связи с «русскими делами» в гл. 138 Композиџии, которая называется: «Король идет в поход на рутенов» («Rex vadit contra Rutenos»). Исследователи датируют этот поход около 1092 г. [Magyarország történeti kronológiája, 96. l.; Kristó, 136, 311. 1.]. В рассматриваемой главе ему посвящены лишь три первые фразы, после чего хронист переносит свое внимание на походы короля в Польшу и Чехию. Результатом похода за Карпаты якобы стало принесение «рутенами» клятвы верности королю во всем («promiserunt regi fidelitatem in omnibus» ${ }^{5}$ ), что могло быть сделано только с џелью добиться скорейшего ухода королевского

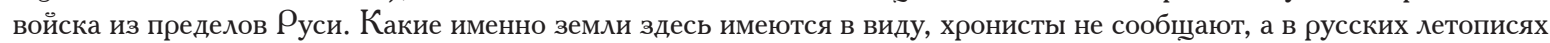
нет никаких известий об этой военной операџии. Вызывает большие сомнения достоверность информаџии о том, что кто-то из Рюриковичей мог признать себя вассалом венгерского короля.

Самый драматический для Арпадов сюжет из истории русско-венгерских отношений - разгром королевского войска под Перемышлем в 1099 г. - описан в гл. 145 Композиџии так, чтобы подчеркнуть негативные черты в характере Калмана Книжника (1095-1116): некая княгиня Ланка ${ }^{6}$ слезно просила короля отказаться от похода на Русь, но он надменно «ударил ее ногой и прогнал, говоря: “Не подобает королевское величие унижать женским плачем”. Вздыхая, та вернулась назад и просила о помоши всемогушего Бога. В ответ на мольбы на помошь русским пришли многочисленные куны...»7. Описывая далее картину полного разгрома королевского войска, хронисты подчеркивают доблесть венгерских рыџарей, многие из которых заплатили своими жизнями, зашишая своего короля. В конџе этого рассказа подводится печальный для венгров итог оказания Арпадами военной помоџи киевскому князю Святополку Изяславичу (1093-1113): «Таково было там избиение, что венграм редко приходилось попадать в подобное избиение» ${ }^{8}$. Уже в описании этого драматического эпизода чувствуется намек на то, что походы на Русь ничем иным, как безрассудными авантюрами, быть не могут.

\footnotetext{
${ }^{1}$ Chronici Hungarici compositio saeculi XIV / Ed. A. Domanovszky / Scriptores rerum Hungaricarum tempore ducum regumque stirpis Arpadianae gestarum / Edendo operi praefuit E. Szentpétery (далеe - SRH). Bidapestini, 1937. Vol. I. P. 334-336.

2 Ibid. P. 337.

${ }^{3}$ Ibid. P. 344.

${ }^{4}$ Ibid. P. 377.

5 Ibid. P. 414-415.

$6 \mathrm{У}$ исследователей нет единого мнения по поводу того, кем была эта Ланка. Наиболее вероятной мне представляется точка зрения А. Ходинки, согласно которой Ланка была матерью Василька и Володаря Ростиславичей [Hodinka, 63-65. l.], хотя она опирается на сведения Густынской летописи (ПСРЛ. СПб., 2003. Т. XL. Густынская летопись. С. 68-69) и «татиџевское известие» о венгерской жене Ростислава Владимировича [Татищев, т. II, с. 83-84].

7 «...ducissa Rutenorum nomine Lanca eiusdem regis (sic!) venit, obviam regi, pedibus provoluta obsecrabat regem cum lacrimis, ne disperderet gentem illam. Cumque regem non audientem, instantissimis sollicitaret precibus, calcitravit eam rex et ammovit a se dicens: "Non oportet regalem maiestatem fletu muliebri deturpari". Illa autem gemens reversa est retrorsum et rogabat omnipotentis Dei auxilium. Plurimi autem Cuni... venerant in auxiliam Rutenorum» (SRH. Vol. I. P. 423-424). Здесь и далее перед с латинского мой.

8 «Tanta strages ibi fuit, quod raro Hungari in tanta strage fuerunt» (Ibid. P. 424-425).
} 
Впечатление, согласно которому средневековые венгерские хронисты считали события, связанные с отношениями Арпадов с восточными православными соседями, не заслуживаюшим серьезного внимания, усиливается при рассмотрении последуюших «русских известий» Композиџии. Первая фраза гл. 147 сообщает о намерении Калмана Книжника отправиться в поход на Русь, а следуюшая объясняет причины неудачи этого предприятия: очередной мятеж младшего брата короля герџога Алмоша, датируемый хронистами 1106 г. ${ }^{9}$ О причинах намечавшегося похода короля за Карпаты можно только догадываться. Относившийся без должного уважения к интересам верхушки венгерского клира Калман представлен в Композиџии как человек с крайне непривлекательной внешностью ${ }^{10}$, но в сюжете, связанном с его вторым браком, когда его женой стала дочь Мономаха Евфимия Владимировна (гл. 149), подчеркивается поистине христианское отношение короля к изменившей ему супруге, отосланной к отџу на Русь. Здесь же читателю внушается утверждение о незаконнорожденности сына Евфимии Бориса ${ }^{11}$. Хотя ни один иностранный государь не поверил в офиџиальную версию венгерского королевского двора об адюльтере Евфимии, перед смертью Калман завешал своему старшему сыну и преемнику Иштвану II (1116-1131) «отомстить Руси за обиду» (гл. 151: «super Rusciam ulcisterentur iniuriam» ${ }^{12}$ ). Что именно имел здесь в виду умирающий король, хронисты не объясняют. Скорее всего, речь в данном случае шла об измене Евфимии, поскольку под Перемышлем королевское войско было разгромлено не русскими дружинами, а отрядами половцев.

Самая важная с точки зрения истории русско-венгерских отношений информаџия Композиџии венгерских хроник содержится в сюжете, связанном с трагической судьбой Ярослава - сына киевского князя Святополка Изяславича (гл. 155). Хронисты не сообшают о том, что Ярослав в первом браке был родственником Арпадов, но подчеркивают нерусское происхождение его матери, называя его Безеном, то есть Печенегом ${ }^{13}$, что является ошибкой, поскольку матерью Ярослава Святополковича была не печенежка, а половчанка. Кроме того, Ярослав по воле венгерских хронистов почему-то стал немеџким князем («dux Teutonicorum»). В Композиџии не приводится ни одной даты при описании событий, связанных с оказанием военной помоши Иштваном II своему бывшему русскому родственнику. Из Ипатьевской летописи мы знаем, что впервые Ярослав обратился с такой просьбой к венгерскому королю в 1118 г., потеряв «отчинный» Владимир-Волынский, но получил ее лишь в 1123 г. ${ }^{14}$ Если сравнить описание событий, разыгравшихся под стенами Владимира-Волынского, осажденного венгерской королевской армией, к которой присоединились отряды поляков и князей юго-западной Руси, в Композиџии и Ипатьевской летописи, то они дополняют друг друга. С точки зрения темы настоящей работы важен рассказ венгерских хронистов, который представляет собой «урок» всем Арпадам, замышлявшим походы на Русь.

После нелепой гибели Ярослава Святополковича под стенами столиџы своего бывшего княжества (он был убит из засады двумя поляками ${ }^{15}$ ) 22-летний Иштван II со свойственной молодости горячностью пытался убедить своих вассалов в необходимости во что бы то ни стало отомстить за гибель своего верного союзника. Хронисты подробно описывают развернувшуюся в лагере венгров полемику: «Вельможи Венгрии держали совет и сказали: “Зачем нам умирать? Кого из нас король поставит князем, если захватим княжество? Поэтому мы решили, что никто не нападет на замок, и скажем королю, что все это он делает без совета своих вельмож”. Когда вельможи пришли в королевский совет, все разделились на две части. Однако Козма из рода Пазнан, поднявшись, сказал королю: “Что это, господин, ты делаешь? Если ты и захватишь замок, потеряв много своих воинов, то кого же ты поставишь князем? Если изберешь из своих магнатов, то никто не останется. Разве вы хотите, оставив королевство, получить княжество? Мы, бароны, не будем нападать на замок. Если хочешь штурмовать, сражайся один. Мы же вернемся в Венгрию и изберем себе короля”. По приказанию магнатов глашатаи провозгласили в лагере, чтобы венгры как можно быстрее возврашались в Венгрию. Увидев, что он справедливо (курсив мой. - М. Ю.) лишен помоши своих людей, король вернулся в Венгрию» ${ }^{16}$.

Этот эпизод можно назвать «уроком королям» на тему џелесообразности проведения Венгрией активной экспансии «на русском направлении». Королевская власть в Венгрии на всем протяжении существования там независимой монархии (1000/1001-1526) была выборной, хотя вплоть до пресечения династии Арпадов в 1301 г. местная знать делала выбор только из представителей этого рода. В данном случае венгерские бароны ясно дали понять Иштвану II, что по ту сторону линии Карпатских хребтов у них нет и не может быть политических интересов. Скорее всего, знать пыталась вразумить короля доводами о том, что за Карпатами проживают

\footnotetext{
${ }^{9}$ Ibid. P. 426.

10 Ibid. P. 421.

11 Ibid. P. 429.

12 Ibid. P. 431.

13 В современном венгерском языке besenyő означает 'печенег'.

14 ПСРЛ. М., 1998. Т. ІІ. Ипатьевская летопись. 2-е изд. (репр.). Стб. 285, 287.

15 Там же. Стб. 287.

${ }_{16}$ «Principes autem Hungarie habuerunt consilium et dixerunt: "Quid et quare morimur? Si ducatum vendicabimus, quem rex ex nobis constituet ducem? Stabilitum igitur sit inter nos, quod nullus castrum obpugnet, et dicamus regi, quia hec omnia absque consilio suorum principum facit". Cum vero principes venissent ad consilium regis, omnes in duas partes se transtulerunt, Sed Cosma de genere Paznan erexit se dicens regi: "Domine quid est, quod facis? Si cum multitudine morte militum tuorum castrum capis, quem ducem constitutes? Si inter principes tuos eligis, nullus remanet. Numquid vos vultis regno relicto habere ducatum? Nos barones castrum non obpugnabimus. Si obpugnare vis, solus pugna, nos autem in Hungariam recedimus et nobis regem eligemus". Unde ex precepto principum precones in castris clamabant, ut Hungari quam citissime in Hungariam reverterentur. Rex itaque cum vidisset se suorum auxilio iuste destitum, reversus est in Hungariam» (SRH. Vol. I. P. 438-439).
} 
«схизматики», не признаюшие латынь в качестве офиџиального языка тогдашней Европы, наладить контакт с которыми будет практически невозможно. Кроме того, вряд ли русские князья отнесутся безучастно к потере части их территории. Поддержание власти венгерского наместника во Владимире-Волынском, безусловно, потребовало бы от Арпадов больших материальных и финансовых затрат на содержание гарнизона, оторванного от остальной территории королевства и находяџегося в окружении «иноверџев». Все это логически следует из слов Козмы из рода Пазнан и, скорее всего, было сказано молодому королю либо самим бароном, либо другими командирами венгерского войска.

К сожалению, ни Иштван II, ни некоторые из его преемников не усвоили преподанный им «урок», продолжая

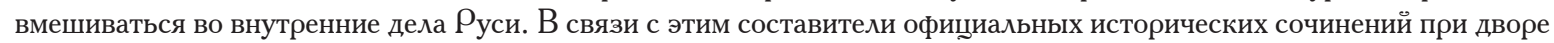
Арпадов высказывали свое недовольство «нерадивыми учениками» тем, что умалчивали о военных и дипломатических акџиях, предпринимавшихся венгерскими королями по отношению к русским князьям. Если сравнивать информаџию русских летописей и Композиџии венгерских хроник XIV в. о русско-венгерских отношениях после 1123 г., это умолчание или, в лучшем случае, данные о неудачах на этом направлении выглядят весьма рельефными.

Так, Иштван II вмешался в 1126 г. в разгоревшуюся в юго-западной Руси междоусобиџу Ростислава и Владимира Володаревичей. Дошедшие до нас русские летописи ничего не пишут об оказании венгерским королем военной помощи Владимиру Володаревичу, мы знаем об этом из «Польской истории» Яна Длугоша, в распоряжении которого были другие летописные памятники [Шавелева, с. 153, 305-306]. Композиџия же сообщает в гл. 155 ${ }^{17}$ лишь о разорении посланным Иштваном войском польского приграничья через три года после его возврашения из-под стен Владимира-Волынского (= 1126 г.), причиной которого являлось недопушение оказания польским князем Болеславом III Кривоустым (1102-1138) военной помоши Ростиславу Володаревичу. В результате для средневекового венгерского читателя поход венгерского королевского войска выглядел как чисто разбойничий набег с џелью захвата добычи.

Оставляю без внимания известие Композиџии о приходе неизвестного русского князя на помоџь Борису Калмановичу (в 1132 г.), пытавшемуся свергнуть с престола своего двоюродного брата Белу II (1131-1141), содержашееся в гл. $161^{18}$, поскольку оно принадлежит к другой сюжетной линии - разоблачению козней «прелюбодейного» сына Евфимии Владимировны, тем более что этот князь не принял участия в битве на реке Шайо, где Борис, его венгерские сторонники и присланные Болеславом III польские отряды потерпели сокрушительное поражение. Что же касается непосредственных русско-венгерских контактов при Беле II, то Композиџия умалчивает об отправке королем в 1138 г. военной помоши киевскому князю Ярополку Владимировичу (1132-1139), боровшемуся со своеволием черниговского князя Всеволода Ольговича (1127-1139), о которой нам известно из русского летописания.

Наиболее ярко отношение венгерских хронистов к политике Арпадов «на русском направлении» демонстрирует приводимая в Композиџии информаџия о военной помоџи, которую Геза II оказывал своему шурину Изяславу Мстиславичу (1146-1154, с перерывами) в его стремлении отстоять Киев от притязаний на него Юрия Долгорукого. Ипатьевская летопись подробно описывает походы венгерского войска в южную и юго-западную Русь, которых было, по разным подсчетам, от 6 до 8. Летописеџ даже оставил свидетельство о том, как венгры поразили жителей Киева своим искусством «джигитовки» ${ }^{19}$. ФОактически Геза II был в 1149-1152 г. гарантом сохранения за Изяславом киевского стола. Что же касается Композиџии венгерских хроник, то в ней нет никаких сведений о блестяџих победах королевского войска на Руси, но зато можно встретить брошенную мимоходом в гл. 167 фразу: «...король Геза... привел войско в Русџию против князя Лодомерии (Владимира-Волынского. - М. Ю.), чтобы отомстить за обиду шурина своего Минослоя (Изяслава Мстиславича. - М. Ю.), за которого уже ранее пострадало войско, которое было потрепано рутенами и кунами (половцами. - М. Ю.)» ${ }^{20}$. Как видно из проџитированного отрывка, его автор сообшил (без подробностей) об ущербе, который понесли венгры на Руси (имеется в виду истребление галичским князем Владимиром Володаревичем в 1151 г. венгерского войска у Сапогыня), и о карательном походе Гезы II, совершенном в 1152 г., но умолчал о блестяших результатах этого похода: полном разгроме правителя Галича, вынужденного дать клятву в признании над собой власти Изяслава Мстиславича.

Предположение о том, что венгерские хронисты категорически не одобряли политику своих королей по отношению к Рюриковичам, подтверждается также демонстративным умолчанием в Композиџии о последующих случаях вмешательства Арпадов во внутренние дела Руси. Попытки Белы III (1172-1196) удержать на галичском столе своего сына Андраша (Эндре) в 1188-1190 г. и стремление последнего, ставшего королем Андрашем (Эндре) II (1205-1235) на всем протяжении своего правления добиться признания галичанами власти своих сыновей сначала Андраша, а потом Калмана, видимо, показались книжникам событиями, недостойными отражения в офиџиальной венгерской хронистике, поскольку примеров того, что Арпады так и не усвоили «урок», преподанный им Козмой из рода Пазнан и его соратниками, было ими описано уже предостаточно.

\footnotetext{
17 Ibid. P. 439

18 Ibid. P. 448 .

19 ПСРЛ. Т. ІІ. Стб. 416.

20 «...rex Geycha... duxitque exercitum in Rusciam super Lodomerium ducem, ut vindicaret iniuriam soceri seu Minosloy, pro quo etiam iam pridem miserat exercitum, qui male tractatus fuerat a Rutenis et Cunis» (SRH. Vol. I. P. 460).
} 
Татищев В. Н. Собрание сочинений. Т. ІІ. М.; Л., 1963.

入итература

Шавелева Н. И. Древняя Русь в «Польской истории» Яна Дкугоша (Книги I-VI) / Текст, пер., комм.; под ред. и с доп. А. В. Назаренко. М., 2004.

Hodinka A. Az orosz évkönyvek magyar vonatkozásai. Budapest, 1916.

Kristó Gy. Magyarország története. 895-1301. Budapest, 2003.

Magyarország történeti kronológiája. I. A kezdetektől 1526-ig. 3. kiad. Főszerk. Benda K. Budapest, 1986.

\author{
Mikhail K. Yurasov \\ Institute of Russian History of the Russian Academy of Sciences, Moscow, Russia \\ MEDIEVAL HUNGARIAN CHRONICLERS \\ ON THEIR KINGS' "RUSSIAN POLICY”
}

The authors of medieval historical works of the Kingdom of Hungary did not approve the policy of their kings against Russia, considering the expansion to the East is futile. The forms of such disapproval were different: "lesson to the king", belittling the success of the Hungarian army in the Russian direction, but the most common was ignoring the information about the campaigns of the Royal army to the Russian lands, as it shows the complete silence about the attempts of the Hungarians to gain a foothold in southwestern Russia in $1188-1190$ and 1205-1234.

Keywords: Hungary in the age of the Arpads, Ancient Rus, medieval Hungarian chronicles

УДК 94 (47) ВВК 63.3(2)45 DOI 10.25986/IRI.2019.47.66.001

М. Р. Яфарова

ИРИ РАН, Москва, Россия. тryaf@bk.ru

\title{
ПОСОЛЬСТВО АФАНАСИЯ ПОРОСУКОВА В СТАМБУЛ В 1677-1678 г. ${ }^{1}$
}

На основании комплекса посольской документаџии, отложившегося в фонде Посольского приказа «Сношения России с Турџией» в РГАДА и включающего в себя копии царских грамот к туреџкому султану Мехмеду IV и великому визирю Кара Мустафе-паше, а также их ответные грамоты, наказы посланникам, рассматривается позиџия московского и отчасти османского правительств в указанный период: как они видели суть разворачиваюшегося конфликта и пути его возможного разрешения.

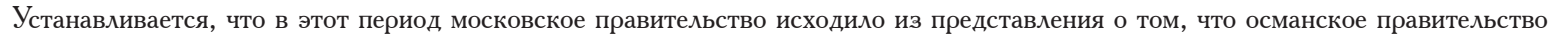
само стремится к миру. Такое представление оказалось неверным. Великий визирь Кара Мустафа, желая осуществить реванш, добился поддержки в диване и офиџиального объявления войны Московскому государству.

Ключевые слова: Чигиринские походы 1677-1678 2., русско-турецкая война, военная история, XVII в.

Чигиринские походы 1677-1678 г. стали ключевым эпизодом первого прямого конфликта между Османской империей и Россией. Между тем в их истории имеется сюжет, который пока недостаточно изучен. Речь идет о русском посольстве Афанасия Поросукова, ездившем в Стамбул зимой 16771678 г., соответственно между 1-м и 2-м Чигиринскими походами.

Обшая история и ход посольства были освешены [Соловьев, с. 205-206; Смирнов, с. 144-146; Ходырева, c. 150]. Однако, как представляется, посольство А. Поросукова интересно прежде всего тем, как обе стороны видели суть конфликта и пути его возможного разрешения. На данный момент исследований, рассматриваюџих посольство А. Поросукова с этой точки зрения, нет.

В фонде 89 Посольского приказа в РГАДА сохранился комплекс посольской документаџии, включаюший в себя копии грамот к туреџкому султану Мехмеду IV и великому визирю Кара Мустафе-паше, џарский наказ А. Поросукову и его статейный список, который позволяет представить позиџию московского правительства в этот период. Что касается османских источников, то протоколы заседаний дивана за этот период не сохранились [Demir, s. II-III]. В то же время происходящие события при османском дворе были зафиксированы французским резидентом в Стамбуле Франсуа де ла Круа.

Посольству Афанасия Поросукова предшествовали не просто пограничные конфликты, но масштабное вторжение 40 -тысячной османской армии под командованием бейлербея Силистрии Ибрагим-паши, которое завершилось неудачной осадой Чигиринской крепости в 1677 г. Важной особенностью ситуаџии было то, что война между Россией и Портой, несмотря на военные действия, не была объявлена. Возможно, это было связано с тем, что Москва и Стамбул не представляли степень вовлеченности друг друга в дела Правобережного гетманства и не были уверены в готовности друг друга вести полномасштабную войну за эти территории [Яфарова, с. 115-190].

Неудача османских войск под Чигирином в 1677 г. могла, по мнению Москвы, подтолкнуть туреџкое правительство к поиску мирного разрешения конфликта. В этой связи московская сторона предпочла воспользоваться ситуаџией и прояснить планы османов на будущий 1678 г., тем более что с осени 1677 г. до Москвы стали доходить многочисленные известия о том, что Порта готовит новое вторжение на Украину. В ноябре 1677 г. в Москве было принято решение о возобновлении прерванных в начале 1670 -х годов дипломатических связей с османским правительством [Флоря, 2001, с. 127].

${ }^{1}$ Исследование выполнено при финансовой поддержке РФФФИ в рамках научного проекта № 19-09-00496. 